\title{
Kajian Vaksin Avian Influesa (AI) pada Ayam Buras dengan Sistem Kandang Kurung di Gunung Kidul Yogyakarta
}

\author{
W. Suwito ${ }^{1}$, Supriadi $^{1}$, E. Winarti ${ }^{1}$, dan R. A. Primatika ${ }^{2}$ \\ ${ }^{1}$ Balai Pengkajian Teknologi Pertanian Yogyakarta \\ Jl. Stadion Baru Maguwoharjo No. 22 Karang Sari, Wedomartani, \\ Ngemplak, Sleman, Yogyakarta (0274) 884662.e-mail:widodo.suwito@yahoo.com \\ ${ }^{2}$ Laboratorium Kesehatan Masyarakat Veteriner, \\ Fakultas Kedokteran Hewan, Universitas Gadjah Mada. \\ Jl Fauna no 2, Yogyakarta 55281
}

\begin{abstract}
ABSTRAK
Avian influenza (AI) merupakan penyakit yang sangat mematikan pada ayam buras. Vaksinasi AI merupakan salah satu alternatif pencegahan penyakit AI. Tujuan dari penelitian ini adalah untuk mengetahui efektivitas vaksin AI pada ayam buras yang dipelihara dengan sistem kandang kurung di Gunung Kidul Yogyakarta. Sebanyak 110 ekor ayam buras yang terdiri dari 100 ekor dara dan 10 ekor jantan digunakan dalam penelitian ini. Ayam ditempatkan dalam kandang dari bambu berukuran $5 \times 4 \mathrm{~m}^{2}$ yang masing-masing kandang diisi 10 ekor ayam dara dan satu ayam jantan.Vaksin yang digunakan dua macam yaitu vaksin AI komersial (A) dan vaksin AI lokal (B). Masing-masing vaksin dengan dosis 0,5 ml diberikan secara intramuskuler (i.m) pada 55 ekor ayam. Vaksinasi ulang dilakukan setelah dua bulan pascavaksinasi. Pemeriksaan titer antibodi AI dilakukan pada bulan ke-2, 3, 4, 5 dan 6 dengan pengambilan darah ayam melalui vena brakhialis pada sayap. Vaksin AI komersial A dan lokal B protektif pada ayam buras sistem kandang kurung setelah 2 bulan vaksinasi dan dilanjutkan dengan vaksin ulang.
\end{abstract}

Kata kunci: Avian influenza (AI), vaksin, ayam buras

\section{Study of Avian Influenza Vaccine in Local Chicken at Enclosure Cage System in Gunung Kidul Yogyakarta}

\begin{abstract}
Avian influenza (AI) is highly pathogenic desease in local chicken. Avian influenza (AI) vaccine is one of choice to prevent AI desease. The purpose of these study was to determine the effectiveness of AI vaccine in local chicken at the enclosure cage system in Gunung Kidul, Yogyakarta. A total of 110 local chicken consist of 100 hen and 10 cock were used in these study. The chicken was stored in cage of bamboo that have a measurement of $5 \times 4 \mathrm{~m}^{2}$ include 10 hen and 1 cock in cage respectively. The vaccine used in these study was 2 kinds of commercial AI vaccine (A) and local AI vaccine (B). Vaccine with $0.5 \mathrm{ml}$ dose was administrated by intramuscular (i.m) in 55 local chicken respectively. Re-vaccination was administrated after 2 month first vaccination. Examination of antibody titer AI was performed at month 2, 3, 4, 5 and 6 with chicken blood sampling collection via the brachial vein in the wing. Avian influenza vaccine commercial A and local B were protective in local chicken with enclosure cage system after 2 month vaccination and followed by booster.
\end{abstract}

Key words: Avian influenza (AI), vaccine, local chicken 


\section{PENDAHULUAN}

Ayam buras merupakan ternak unggas yang sangat umum dipelihara di daerah pedesaan. Manfaat yang diperoleh dari beternak ayam buras antara lain menghasilkan telur, daging, sebagai tabungan, dan dapat memanfaatkan sisa dari limbah rumah tangga. Kandang, pakan yang cukup, dan faktor kesehatan merupakan hal yang penting dalam pemeliharaan ayam buras. Saat ini penyakit ayam yang masih menjadi perhatian serius adalah Avian Influensa (AI) atau flu burung.

Penyakit AI disebabkan oleh virus influenza A yang mempunyai subtipe dengan 15 hemagglutinin $(\mathrm{H} 1-\mathrm{H} 15)$ dan 9 Neuramidase (N1-N9) yang berbeda (Tumpey et al., 2001). Secara garis besar virus influenza dibagi kedalam tiga golongan yaitu A, B dan C. Pengolongan tipe virus berdasarkan kandungan protein hemaglutinin $(\mathrm{H})$ dan neuraminidase $(\mathrm{N})$ yang terdapat pada permukaan virus. Kandungan kedua protein tersebut yang menentukan virus tersebut bersifat high patogenik atau low patogenik. Protein neuraminidase $(\mathrm{N})$ selain menentukan tingkat patogen virus juga sebagai determinator atau penentu jenis hospes (host) virus. Hospes virus dapat bertahan hidup pada burung, itik, babi atau pada manusia.

Virus AI bertahan hidup dalam kotoran ayam dalam waktu yang lama sedangkan pada air selama 32 hari. Virus AI bersifat labil sehingga mudah berubah sifat dari tidak ganas menjadi ganas atau sebaliknya. Penyakit AI dapat bersifat mematikan unggas dan bersifat zoonosis yang dapat menular ke manusia. Vaksinasi merupakan salah satu alternatif dalam pencegahan AI pada ayam buras. Selain vaksinasi secara rutin, pengkandangan ayam merupakan salah satu tindakan yang dapat mengendalikan penyakit AI. Tujuan pengkandangan ayam adalah untuk menghindari penularan dan penyebaran penyakit dari dan ke lingkungan, selain itu memudahkan pelaksanaan vaksinasi.
Saat ini vaksin AI banyak dijual bebas di poultry shop dengan berbagai merek. Efektivitas vaksin AI akan lebih baik apabila strain virus dalam vaksin yang digunakan homolog dengan strain virus yang ada dilapangan (Sudarisman, 2006). Pengamatan di laboratorium dan lapangan menunjukkan bahwa vaksin AI yang baik harus memenuhi beberapa persyaratan antara lain: dapat melindungi timbulnya gejala klinis dan kematian, mengurangi shedding virus di lapangan, memberikan waktu proteksi paling sedikit 20 minggu sesudah vaksinasi tunggal atau ulangan, melindungi terhadap tantangan dosis rendah sampai tinggi dari virus lapangan, melindungi perubahan virus lapangan dan meningkatnya daya tahan terhadap infeksi virus influenza (Swayne, 2005). Oleh karena itu tujuan dari penelitian ini adalah untuk mengetahui efektivitas vaksin AI pada ayam buras yang dipelihara dengan sistem kandang kurung di Gunung Kidul Yogyakarta.

\section{MATERI DAN METODE}

\section{Materi Penelitian}

Sebanyak 110 ekor ayam buras yang terdiri dari 100 ekor dara dan 10 ekor jantan. Ayam tersebut dibagi dalam 2 perlakuan dan ditempatkan dalam 10 kandang. Kandang terbuat dari bambu berukuran $5 \mathrm{x}^{2} \mathrm{~m}^{2}$ yang masing-masing kandang diisi 10 ekor ayam dara dan satu ayam jantan. Seminggu sebelum dilakukan vaksinasi ayam diberikan obat cacing dan vitachick dalam air minum sedangkan pakan terdiri dari bekatul dan jagung yang diberikan secara ad libitum. Vaksin yang digunakan dua macam yaitu vaksin AI komersial (A) dan vaksin AI lokal (B). Masing-masing vaksin dengan dosis 0,5 $\mathrm{ml}$ diberikan secara intramuskuler (i.m) pada 55 ekor ayam. Saat pertama kali vaksinasi semua ayam diambil darahnya untuk dilihat titer antibodi AI sebelum vaksinasi. Vaksinasi ulang atau booster dilakukan setelah dua bulan pascavaksinasi. Pengamatan hasil vaksinasi dilakukan pada bulan ke-2, 3, 4, 5 dan 6 dengan 


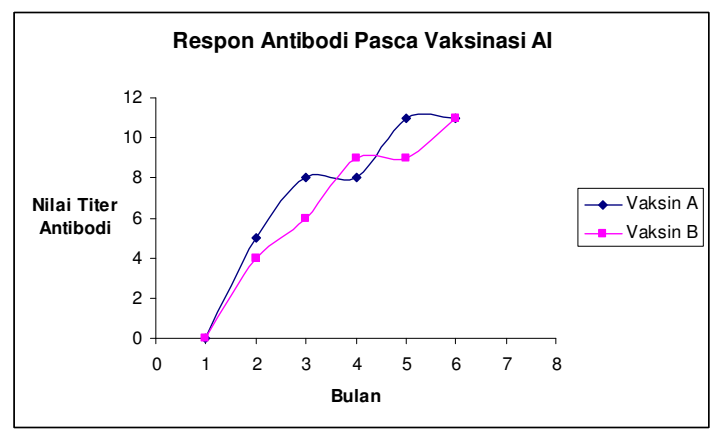

Gambar 1. Rerata respon Antibodi AI selama 6 bulan

pengambilan darah melalui vena brakhialis pada sayap. Pemeriksaan titer antibodi AI dari darah ayam dengan haemagglutination nhibition (HI) (OIE, 2004).

\section{Analisis Data}

Titer antibodi dan produksi telur dari masing-masing kelompok vaksin AI komersial (A) dan lokal (B) dianalisis dengan uji T-test (Nasrullah, 1992) sementara hasil pengamatan titer antibodi dan produksi telur pada pada minggu ke-2, 3, 4, 5 dan 6 dianalisis secara deskriptif.

\section{HASIL DAN PEMBAHASAN}

Respon antibodi AI selama 6 bulan disajikan dalam (Gambar 1). Saat pengambilan darah bulan ke-1 nilai titer antibodi AI menunjukkan 0. Hal tersebut menunjukkan bahwa semua ayam tersebut belum memiliki kekebalan terhadap AI. Vaksinasi diharapkan dapat menimbulkan antibodi yang dapat menetralisasi protein hemaglitinin dan neuramidase virus AI. Berbagai vaksin dapat menimbulkan antibodi baik vaksin hidup maupun mati (Suarez dan Schultz-Cherry, 2000).

Satu bulan pascavaksinasi titer antibodi ayam yang divaksin A dan B menunjukkan peningkatan dengan nilai titer antibodinya 4 dan 5 . Titer antibodi $>4$ dapat memberikan proteksi terhadap penyakit AI sekitar 75\% (Swayne, 2005). Pada bulan ke3 atau dua bulan pascavaksinasi titer antibodi masih naik dengan rata-rata titer antibodi 8 untuk vaksin A dan 5 untuk vaksin B. Nilai titer antibodi antara 6-8 dapat memberikan tingkat proteksi $100 \%$ (Swayne, 2005). Oleh karena itu vaksin A pada bulan ke-3 atau dua bulan pascavaksinasi sudah protektif terhadap AI $100 \%$, sedangkan vaksin B tingkat proteksinya hampir $100 \%$. Kriteria vaksin AI yang baik dalam uji coba di lapangan dapat melindungi terhadap timbulnya gejala klinis dan kematian, menurunkan dan menghentikan virus shedding pada ayam yang telah divaksinasi, mencegah penularan dari virus lapangan, memberikan proteksi selama 20 minggu sesudah vaksinasi, melindungi unggas terhadap perubahan virus atau pergeseran antigenik dan meningkatkan resistensi ayam terhadap infeksi AI (Swayne, 2005; Swayne dan Halvorson, 2003; Capua et al., 2004).

Vaksin ulangan atau booster dilakukan pada bulan ke-3 atau dua bulan pascavaksinasi pertama dengan tujuan untuk meningkatkan nilai titer antibodi. Satu bulan setelah dilakukan booster atau minggu ke-4 nilai titer antibodi untuk vaksin A dan B masing-masing 7 dan 9. Nilai titer antibodi satu bulan setelah dilakukan booster belum meningkat walaupun masih bersifat protektif. Hal tersebut dapat disebabkan efek dari booster belum bereaksi sehingga nilai titer antibodi belum naik. Pada minggu ke-5 atau dua bulan pascavaksinasi nilai titer antibodi menunjukkan peningkatan untuk vaksin A dan B masing-masing 12 dan 8 Pada minggu ke-6 atau tiga bulan pascavaksinasi nilai titer antibodi antara vaksin A dan B sama yaitu 11 (Gambar 1). 


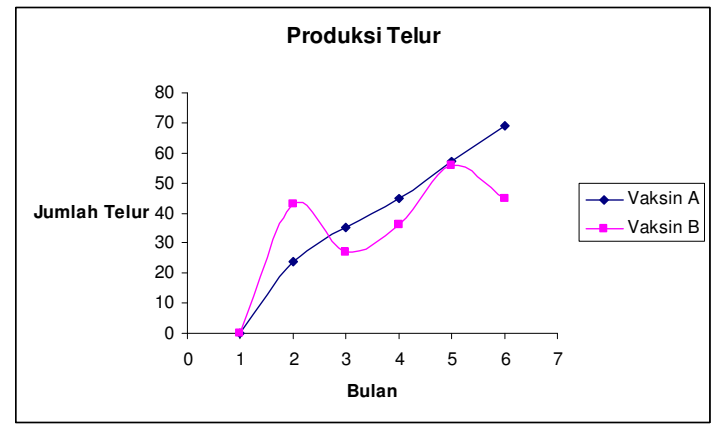

Gambar 2. Produksi telur ayam yang divaksin A dan B selama 6 bulan

Berdasarkan uji T-test nilai titer antibodi antara ayam yang divaksin A dan B pada waktu yang sama tidak ada perbedaan yang signifikan $(\mathrm{P}>0,005)$. Oleh karena itu vaksinasi AI pada ayam buras dapat menggunakan salah satu dari kedua jenis vaksin tersebut.

Produksi telur dari ayam yang diberi vaksin A dan B selama 6 bulan disajikan dalam (Gambar 2 ). Pada bulan ke-1 semua ayam belum bertelur dan baru mulai bulan ke-2 ayam mulai bertelur. Pada bulan ke-2 ayam yang divaksin dengan vaksin A jumlah telurnya 24 butir sedangkan vaksin B 43 butir. Pada bulan ke-3 ayam yang divaksin dengan vaksin A jumlah telurnya 35 butir sedangkan vaksin B 27 butir. Pada bulan ke4 ayam yang divaksin dengan vaksin $\mathrm{A}$ jumlah telurnya 55 butir sedangkan vaksin B 36 butir. Pada bulan ke-5 ayam yang divaksin dengan vaksin A jumlah telurnya 57 butir, sedangkan vaksin B 56 butir dan bulan ke-6 ayam yang divaksin dengan vaksin A jumlah telurnya 69 butir sedangkan vaksin B 45 butir.

Jumlah telur yang dihasilkan mulai minggu ke-2 sampai ke-6 dari kelompok ayam yang divaksin $A$ dan $B$ sangat bervariatif (Gambar 2). Berdasarkan uji $T$ test produksi telur antara ayam yang divaksin A dan B tidak ada perbedaan yang signifikan $(\mathrm{P}>0,005)$. Oleh karena itu penggunaan vaksin A dan B pada ayam dalam produksi telur tidak ada perbedaan. Vaksin tersebut cukup protektif dalam melindungi penyakit AI sampai pada 2 minggu pascavaksinasi pertama dan dilanjutkan dengan vaksinasi ulangan atau booster.

\section{SIMPULAN}

Vaksin AI komersial A dan lokal B protektif pada ayam buras sistem kandang kurung pada dua bulan setelah vaksinasi pertama yang selanjutnya dilakukan vaksin ulang atau booster.

\section{UCAPAN TERIMA KASIH}

Ucapan terima kasih disampaikan kepada Dinas Peternakan Gunung Kidul atas bantuannya selama penelitian berlangsung.

\section{DAFTAR PUSTAKA}

Capua, I., C. Terregino, G. Cattoli and A.Toffan. 2004. Increased resistance of vaccinated turkeys to experimental infection with H7N3 low pathogenicity avian influenza virus. Avian Pathology. 33:158-163.

Nasrullah. 1992. Pengantar Biostatistika. Vol. 2. Gadjah Mada University Press Yogyakarta.

Office International des Epizooties. 2004. Highly pathogenic Avian Influenza. Manual of Diagnostic Tests and Vaccines for Terrestrial Animal. 5th Ed. Chapter 2.1.14.

Sudarisman. 2006. Pengaruh penggunaan vaksin $\mathrm{H} 5 \mathrm{~N} 1$ dan $\mathrm{H} 5 \mathrm{~N} 2$ virus avian influenza pada peternakan unggas di Jawa Barat. Dalam: Seminar Teknologi Peternakan dan Veteriner. Puslitbang Peternakan Bogor. Hal: 766-773. 
Suerez, D.L. and S. Schultz-Cherry. 2000. Imunology of avian influenza virus: a review. Developmental and Comparative Immunology. 24:269-283.

Swayne, D and D.A. Halvorson. 2003. Influenza. In: Diseases of Poultry, 11th Ed. Iowa State Univ. Press, Ames, IA. Pp135-160

Swayne, D. 2005. Avian influenza, poultry vaccines: a review. A ProMed-mail post (http://www.premedmail.org). diakses 1 November 2013.

Tumpey, T.M., M. Renshaw, J.D. Clements and J.M. Katz. 2001. Mucosal delivery of inactivated influenza vaccine induces Bcell dependent heterosubtypic crossprotection against lethal influenza A H5N1 virus infection. Journal of Virology. 75:5141-5140. 